\title{
Conflict concerns disrupt panels, cloud testimony
}

Researchers resign from Academy committees
DNA fingerprinting suit alleges undisclosed ties

\section{Washington}

DURING the past year and a half, six members of two genetics panels at the National Academy of Sciences (NAS) have resigned or been asked to drop their connections with private companies because of concerns that commercial ties might affect their scientific judgement. This unprecedented rash of concern about conflict of interest sharpens the debate over how to separate science and commerce. The relationship is especially murky within genetics, where today's scientific discovery may be tomorrow's commercial products.

While many in the scientific community continue to play down the problem of conflict of interest, the NAS moves have not gone unnoticed. In Congress, Representative Don Edwards (Democrat, California), chairman of the House Judiciary Committee's subcommittee on civil and constitutional rights, plans some time this spring to hold hearings over concerns about conflict of interest among the scientific proponents of DNA 'fingerprinting'. Earlier this month, lawyers who argued (and lost) a landmark DNA fingerprinting case in 1989 petitioned to have the case reopened, saying that geneticists who gave expert testimony did not disclose their commercial ties. And the Council for Responsible Genetics, a research watchdog group, wants tougher ethical standards.

At the NAS, the problem of conflict of interest among panel members has become so serious that officials have been forced to create a new class of committee - a nonvoting 'liaison panel' - exclusively for affected researchers. When the NAS's Institute of Medicine (IOM) reviewed the membership of its new genetic screening panel (known as the Committee on Predicting Future Diseases) last year, it asked the chairman, C. Thomas Caskey, and two other panel members to step down because of concern about their ties to industry. The two panel members, Frank Fujimura and Philip Reilly, agreed to sit on an associated liaison panel, but Caskey decided to leave the committee entirely.

Even when the IOM picked a new chairman for the genetic screening panel, conflict of interest once again reared its head. Before Arno Motulsky, a University of Washington geneticist, could take the post, IOM officials asked him to resign from the advisory board of GeneScreen Inc., a major genetic screening company, and sell his stocks in the company. He says he agreed out of a "sense of duty to IOM" and because the amount of money involved was relatively small.

But the debate over conflict of interest in genetic testing pales compared with the open warfare now being waged over DNA fingerprinting, where ideology (law and order vs civil rights) and the prospects of substantial profits have splintered the genetics community. At the centre of the controversy is Caskey, a Baylor College of Medicine geneticist and a tireless promoter of DNA fingerprinting as a forensic technique. On 21 December 1991, six months after he had resigned from the IOM genetic screening panel and two days after an article in Nature $(\mathbf{3 5 4}, 500,1991)$ described his financial connections to a major DNA fingerprinting company, Caskey resigned from a NAS panel doing a report on DNA fingerprinting.

On 8 February 1992, the debate over Caskey's conflicts reached the courts when defence lawyers in a 1989 murder case known as US v. Yee, et al. filed a motion for the case to be reopened. Their motion was based on what they allege was a conflict of interest in expert witnesses, including Caskey, who testified in support of the DNA fingerprinting analysis that sent three men to prison.

Attorneys Barry Scheck and Peter Neufeld allege that Caskey failed to disclose that he had already applied for a grant for $\$ 200,000$ from the National Institute of Justice (NIJ), which is funded by the US Department of Justice, to do DNA fingerprinting research. Although Caskey declined to be interviewed, he submitted an affidavit in the Yee case in which he attests that he did not "personally profit"

\section{Coincidence or conspiracy?}

IN their wide-ranging attack on DNA fingerprinting and its supporters, the two lawyers who have asked to have a landmark DNA fingerprinting case reopened (see story above) are alleging that the American Journal of Human Genetics (AJHG) allowed Federal law enforcement officials to interfere in the peer-review process of a critical paper.

In the paper, Seymour Geisser, a University of Minnesota statistician, criticizes the statistical methods used by the Federal Bureau of Investigation (FBI) in DNA analysis. Late last year Geisser submitted his manuscript for publication in the AJHG. On 15 January, Geisser received a fax from Stephen Redding, a federal prosecutor involved in a Minnesota DNA fingerprinting case in which Geisser was expected to testify for the defence. Redding demanded that Geisser bring to court any of his papers on DNA fingerprinting now pending in any peerreviewed journal, specifically including the AUH, and all correspondence concerning the paper.

Fifteen minutes later, Charles Epstein, editor of the AJHG, faxed Geisser a covering letter warning him to write carefully as the work would certainly be used in court cases, and attached three peer reviews, one of which was exceedingly critical. Late last month, in a court hearing for another DNA fingerprinting case, Ranajit Chakraborty, a population geneticist at the University of Texas Health Science Center, was forced to identify himself as the critical reviewer of the Geisser manuscript. At the hearing, Chakraborty also acknowledged that he is a co-investigator on a $\$ 200,000$ Justice Department grant that is principally intended to generate a series of peer-review articles that would provide better scientific support for the FBI's statistical methods.

The Yee lawyers allege that the 15-minute proximity of the two faxes was no coincidence. They allege that at least one of the reviewers tipped off federal prosecutors, and that the prosecutors essentially ran the peer-review show from there.

Nonsense, says Epstein. He says that "nobody contacted us and we contacted nobody." The letter and reviews were faxed to Geisser two days after the third review came in, a time span entirely determined by Epstein's own schedule, he says.

More worrying, however, is the fact that Epstein says he did not know until it was revealed in the court documents earlier this month that Chakraborty, who is an AJHG associate editor, had the Justice Department grant. Had he known, he says, "I'm not sure I would have used him as a reviewer."

Bias and conflicts in this field of inflamed passions are probably unavoidable; they become a problem only when researchers do not disclose them. With hidden agendas and undisclosed allegiances, Epstein says, "it is becoming increasingly difficult to deal with these papers." The only reason Chakraborty's Justice Department connections came out was because a court required him to disclose them. Just how many potential conflicts in less controversial fields lie hidden remains a nagging question. Chrlstopher Anderson 
from the NIJ award, which, like most grants, was awarded to his institution.

The defence motion in Yee also discloses that another expert witness, Stephen Daiger of the University of Texas Health Science Center, failed to disclose that he had applied for and subsequently won a $\$ 300,000$ grant from NIJ for DNA forensics research. Ranajit Chakraborty, coinvestigator on the NIJ grant with Daiger, says that one of the principal purposes of the grant was to generate a series of peer review articles that would substantiate the FBI's statistical methods.

In a response on 20 February to the petition to reopen the case, James Wooley, assistant US attorney for the US district court in Ohio, rejected the motion as "an all-out bare knuckles, take-no-prisoners assault" on DNA fingerprinting by the "anti-DNA lobby". Those forces, he claims, are trying to "pollute the record with allegations". Because opponents of DNA fingerprinting have usually failed to have DNA evidence dismissed on scientific grounds, he says, they have decided to attack its proponents.

Although the DNA fingerprinting fracas is perhaps the most high-profile of the recent conflict of interest debates, some of the other cases at the NAS have been just as vexing for the researchers involved. Last summer, NAS officials decided to take a closer look at the members of the new genetic screening panel.

After reviewing the standard "conflict and bias" declarations submitted by panel members, NAS officials decided that Reilly, who is executive director of the Shriver Center for Mental Retardation in Waltham, Massachusetts, and Fujimura, scientific director of molecular biology at the Nichols Institute Reference Laboratory in San Juan Capistrano, California, each had a potential conflict of interest. Reilly serves as a member of the board of directors of Vivigen Inc., a diagnostic testing laboratory in Santa Fe, New Mexico, and Fujimura's company is a commercial laboratory that does genetic screening and DNA fingerprinting.

Reilly, for one, was surprised. Neither he nor Fujimura has ever made a secret of his commercial affiliations, he says, and the NAS DNA fingerprinting panel, on which he also serves, had not raised any questions about conflict. In fact, of the eight national advisory panels on which he serves (including those of the National Institutes of Health and the Office of Technology Assessment), only four even required a conflict-of-interest review, he says. And only one institution - the IOM - decided that there was a conflict.

Although Reilly agrees with the IOM decision, he's troubled by the random nature of most reviews of potential conflicts of interest. What is a conflict for one advisory committee may not be one for another, even when they cover the same subject. "The problem is the unevenness of it all," he says.

In some of the other cases, the initial concern came from the researchers themselves. Michael Hunkapiller resigned in 1990 from the NAS DNA fingerprinting panel when he decided that his job as vice president for science and technology for Applied Biosystems Inc. (ABI), a genetics technology company, had become a potential conflict.

He first thought that his employment at a company that made only "generic technology" in the field would not pose a problem in weighing DNA fingerprinting as a member of the NAS committee. But

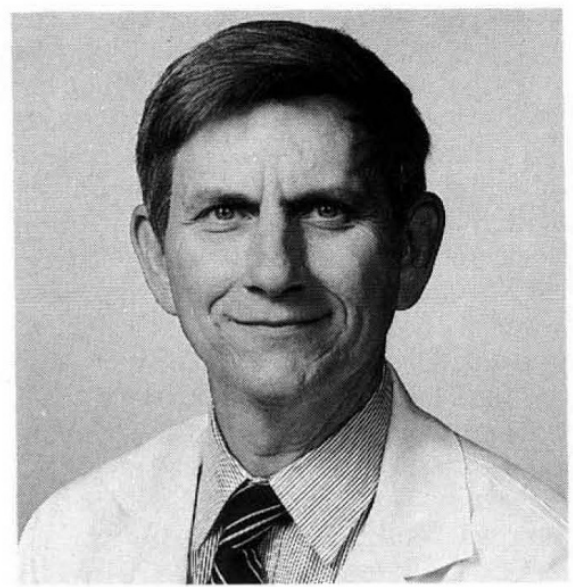

Caskey's industry ties are under fire.

when $\mathrm{ABI}$ decided to market a machine that was specifically applicable to DNA fingerprinting, Hunkapiller asked to be taken off the panel.

But Caskey's case is perhaps the most difficult of all for a scientist. He is both at the forefront of basic genetic research, and deeply involved in the growing genetic testing and diagnostics industry. Beyond the NIJ grant, he has an agreement to license genetics diagnostics technology through Baylor to Cellmark Diagnostics Inc., a major DNA fingerprinting company that was asked by the US Department of Defense to develop methods to identify soldiers killed in the Gulf War. Two other companies are about to conclude similar licence agreements. Royalties from these agreements go to Baylor, not to Caskey directly, according to a spokeswoman.

Caskey is also connected to industry through his wife, Peggy Caskey, who in 1982 founded (and now serves as president of) the Houston-based Laboratory for Genetic Services, Inc., a commercial diagnostics laboratory. Victor McKusick, a Johns Hopkins University geneticist and chairman of the NAS DNA fingerprinting, says this connection was not the panel's principal concern.

"I don't think that what a member of your family does in this regard can be regarded as a conflict," he says. As for the other potential conflicts, McKusick says, "it may be a matter of an oversight here. I think that Caskey's a honest and honorable man." He describes Caskey's affiliation with Cellmark during the Gulf War as a "patriotic duty".

One congressional staff member who has been following the controversy sees it differently. "I don't understand why it wasn't apparent that Caskey had a conflict," he says. "The academy obviously lost control of their process." The House Science, Space and Technology committee had a meeting with academy officials to discuss the issue of conflict and bias in academy reports but, unlike Edwards's justice subcommittee, does not currently plan hearings on the subject.

Although the incidence of conflict appears to be growing, NAS officials say that there is little they can do to uncover potential problems beyond the standard precaution of having each panel member fill out a self-disclosure form, which is updated yearly. They can, however, make sure that the disclosure forms do not become just another formality.

Oskar Zaborsky, IOM staff officer for the DNA fingerprinting panel, asked the panel members to reexamine their potential conflict in December, after the Caskey controversy. And Ruth Bulger, who heads the IOM section in which the genetics screen panel serves, says that she would have "asked earlier" in the process about possible conflicts if she had known that three of the members would be found to have potential problems.

The Council for Responsible Genetics, based in Cambridge, Massachusetts, is leading the internal battle against conflict of interest in the genetics community. As part of a letter-writing campaign to researchers and journals, the council warns that the Human Genome Project is at risk of becoming "compromised by the undisclosed biases of its participants." Paul Billings, a geneticist at the California Pacific Medical Center and member of the Council, says that as a reviewer for the $\$ 5$ million ELSI programme, he has seen several instances of researchers submitting grant proposals that included payments to private companies (such as commercial testing laboratories) in which they had undisclosed financial interests. "It's ironic that the world's largest ethic programme would have this problem," he says.

Although the problem of conflict has been nowhere as apparent as in DNA fingerprinting, where critics and supporters trade allegations of bias and dirty politics, researchers are predicting more battles in genetic screening. As the Human Genome Project begins to fulfil its promise, more geneticists will have to decide just where to draw the line between commerce and pure research - and groups such as the NAS will have an even harder time finding impartial advice.

Christopher Anderson 